\title{
GENERAL CONSIDERATIONS REGARDING THE INTEGRATED INFORMATIONAL SYSTEM OF TRACKING TIMBER-SUMAL IN THE ACTUAL CONTEXT
}

\author{
Anca Elena Bența \\ Doctoral School of Law \\ “Alexandru Ioan Cuza” Police Academy of Bucharest \\ *Correspondence: Anca Elena Benţa, Agora University of Oradea, 8 Piaţa Tineretului St., \\ Oradea, Romania \\ E-mail: ancabenta@yahoo.com
}

A.E. BENŢA

\begin{abstract}
In order to fight the illegal deforestation, as well as to reduce the criminal facts in the forestry field and the inappropriate forestry, it was constituted and implemented the integrated informational system of tracking timber in real time, called SUMAL. This system can provide information regarding the complete tracking of timber, from the moment of harvesting it to the final processing or export.
\end{abstract}

KEY WORDS: ILLEGAL DEFORESTATIONS, TRANSPORTING TIMBER, SUMAL, THE FORESTRY CODE.

As an essential component of the environment, the forest has an important role in maintaining the ecological balance, not only across Europe, but also in the whole world. Thus, an inappropriate forestry can have a series of negative consequences, both immediate and on a long term. Here we take into account the fact that deforestations constitute the main cause of the desert extension, while reducing the forest vegetation favors the greenhouse effect, the global warming ${ }^{1}$ and so on.

In the context of illegal land clearings, of illegal tree cutting and the attempts to limit the negative consequences of these deeds, the European Union undertook a series of actions in the forestry field. The most important are: "The European Union Forestry Strategy"2 from 1998, that establishes the general action context for the sustainable development of forests, "The EU Forestry Action Plan for 2007-2011"3 from 2006 for applying the Strategy, and in 2013 was adopted "A New EU Strategy for Forests and the Forestry Field" proposing a European frame of reference for the elaboration of regional politics impacting the forests ${ }^{4}$, promoting the sustainable management of the forests as a means to protect the biodiversity, to fight the desertification and react to the climate changes ${ }^{5}$. Thus the REDD ${ }^{6}{ }^{6} \mathrm{FLEGT}^{7}$ and

\footnotetext{
${ }^{1}$ Mircea Duţu - "Dreptul internaţional al mediului" (International Environmental Legilation), Editura Economică, Bucureşti, 2004, p.419.

${ }^{2}$ The Ministerial conference regarding the protection of the forests in Europe, Helsinki, 1993.

${ }^{3}$ The Communication of the Committee from June $15^{\text {th }} 2006$ regarding an EU action plan for forests /COM(2006) 302 final

${ }^{4}$ Communication of the Committee from September 20, 2013 called “A New EU Strategy for forests and forestry filed”/COM(2013)659 final

${ }^{5} \mathrm{COM}(2013) 659$ final.

${ }^{6}$ Reducing emissions from deforestation and forest degradation (REDD; REDD + (or REDD-plus) refers to the" emissions reduction caused by the deforestation and degradation of forests in the developing countries, as well as the role of preservation, long term management of forests, conservation of forest carbon stock and increasing the forest carbon stock being "+", in REDD +", according to the European Parliament Resolution from April $23^{\text {rd }} 2009$ regarding the approach of the problems related to deforestations and degradation of forests in order to tackle climate changes and reduction of biodiversity (2010/C 184 E/08).
} 
the EU Regulations regarding the wood exploitation ${ }^{8}$ have as purpose the implementation of these goals.

The EU Timber Regulation (EUTR), adopted on October $20^{\text {th }} 2010$ and implemented starting March $3^{\text {rd }} 2013$ by all the state members of the European Union forbids the placing of illegally cut timber and derived products on the European Union market.

The purpose of this Regulation is reducing to a minimum the risk of placing on the internal market of timber and of products derived from timber obtained through illegal exploitation $^{9}$, stipulating the following obligations ${ }^{10}$ of the agents:

a) banning the placing on the EU market of illegally cut timber and of any products derived from it;

b) the obligation of EU traders who introduce for the first time timber or derived products on the EU market to exercise the „due diligence”;

c)in order to allow the traceability of timber products, the agents or traders must keep track of providers and clients all along the supply chain.

In the Romanian context of illegal deforestation and increase of criminal activity in the forestry field and in order to implement article $73^{11}$ of Law 46/2008 in the Forestry Code, Government Decision no.470/2014 ${ }^{12}$ was adopted in order to control the illegal land clearing and improper exploitation of forests.

This normative act intends to complete the obligations mentioned by The EU Timber Regulation (EUTR) for the agents introducing on the market timber and timber derivates and also to introduce stricter rules regarding the documents accompanying the timber transportation.

According to the provisions of the aforementioned decision, in order to facilitate the timber traceability and purveyance of statistical information, an Integrated Informational System of Tracking Timber in real time, called SUMAL, was instituted.

The necessity of instituting this system appeared after analyzing data showing both the inefficiency of the measures undertaken in order to reduce and limit the illegal timber harvest and the lack of basic information regarding the timber available or entered in the economical circuit.

\footnotetext{
${ }^{7}$ The Regulation (CE) no.2173/2005 regarding the institution of a licenses regime FLEGT for importing timber in the European Community.

${ }^{8}$ Regulation (UE) no. 995/2010 establishing the obligations of operators who introduce timber and timber products on the market.

${ }^{9}$ Without an internationally accepted definition, the legislation of the timber origin country should constitute the basis for establishing the definition of illegal forest exploitation, as shown in paragraph 14 of EU Regulation (UE) no.995/2010 establishing the obligations incumbent on the agents who introduce timber and timber products on the market. This Regulation defines in article 2 letter g) only what "illegally cut" timber means, namely "cut by breaking the applicable law in the country of origin". The letter h) defines what the "applicable law" means, namely "the effective legislation in the country of origin that regulates the following aspects: the rights to cut timber within the legal limits made public; - fees for the timber and harvest rights, including the timber cutting fees; - harvesting the timber, including the environment and forestry legislation, including the forests' management and the preservation of biodiversity when they are directly related to harvesting the timber; - the legal rights of third parties regarding the use and property impacted by timber harvesting; as well as - trading and customs, to the extent that it covers the forestry field."Also, see The EU Regulation (UE) no.363/2012 on procedural rules for the recognition and withdrawal of recognition of monitoring organizations, mentioned by the EU Regulation (UE) no.995/2010 of the European Parliament and the Counsel of establishing the obligations incumbent on the agents who introduce timber and timber products on the market.

${ }^{10}$ According to art.4 and art. 5 from EU Regulation (UE) no.995/2010.

${ }^{11}$ Art.73 has are the following content: "The rules concerning the origin, movement and marketing of timber, the regime of timber storage facilities and installations of processed round wood are established by Government Decision at the proposal of the central public authority responsible for forestry."

${ }^{12}$... for approving the Norms on the origin, movement and marketing of timber, the regime of timber storage facilities and installations to process round wood as well as measures for implementing the Regulation (EU) no. 995/2010 of the European Parliament and of the Council of October20 ${ }^{\text {th }} 2010$ establishing the obligations of agents who place timber and timber products on the market wood, published in the Official Gazetteno.426 of June $10^{\text {th }} 2014$.
} 
The central authority insuring the implementation and proper functioning of the SUMAL system is the Ministry of Environment, Waters and Forests. The system is mandatory for the forest districts and for all the agents and traders who cut, process, store, sell or import-export timber materials.

The main objectives ${ }^{13}$ of SUMAL are:

a) The increase in the efficiency of controls as part of the public politics to reduce the crime level in the forestry field in order to prevent and fight the illegal activity through the control of the timber provenience and traceability; b) Obtaining of statistic information at a national level regarding the volume of timber processed and the resulting wood products;

c) A unified action in the timber bookkeeping by making available to the professionals of a free IT application.

The categories of SUMAL users are ${ }^{14}$ :

- the staff with control attributions from the central public authority responsible for forestry (APCRS) and from the regional special structures of the central public authority responsible for forestry, hereinafter referred to as ITRSV;

- the officers and petty officers from the Romanian Local Police, the Romanian Military Police and the Customs Police;

- forestry staff within forestry districts, higher structures, National Forest Management - Romsilva and the units subordinated to it, as from the Institute of Research and Forestry Arrangements in Bucharest and the subunits subordinated to it;

- employees of the economic agents possessing the distribution agreement of waybills for the transportation of timber, issued according to the legal provisions, hereinafter called agreement;

- employees of the economic agents specialized in transportation with whom the economic agents possessing the agreement signed contracts for the transportation of timber;

- employees of customs authorities where the customs clearance is done, specially enabled by the General Direction of Customs.

The Monitoring System of the timber tracking from the forest till the final beneficiary is put into operation starting from the moment of marking the trees in the forest in view of exploitation and the act of valorization is issued. (AVP).

The timber destined to be cut is registered in the SUMAL and receives a unique code. This code will be written in the waybills and the timber missing this unique code will be confiscated as it has no legal provenience.

The advantage of the SUMAL system consists in the fact that the timber to be cut is identified and prepared in order to be tracked in real time, even before the trees are cut ${ }^{15}$.

For this to be achieved, all professionals must be equipped with smart phones or tablets capable of a permanent connection with SUMAL or any electronic terminal using the SUMAL application. This application is available for free for the users mentioned in art.2 paragraph (4) from the aforementioned decision, that is: forest districts and all agents and traders, called professionals, who cut, process, store, trade or import-export timber. These do not include the agents and traders that cut, store, process, trade or import-export with ornamental trees, shrubs, osier and saplings.

According to the provisions of art. 2 paragraph (7) from the Government Decision no.470/2014, the acts of valorization, the authorizations to exploit the lots, the documents to

\footnotetext{
${ }^{13}$ According to Art. 2 of the Methodology Regarding the organization and functioning of SUMAL, the obligations of SUMAL users, as well as the structure and mode of transmission of standard information, approved by the Order No. 837/2014 published in the Official Gazette no.761 of October $21^{\text {st }} 2014$.

${ }_{14}$ According to Art. 3 from the Methodology approved by Order No.837/2014.

${ }^{15}$ According to the provisions in art. 3 and art. 6 from the Government Decision no. 470/2014, and art.72 from the Forestry Code.
} 
recover the lot sand the confiscation minutes are mandatorily registered by the forest districts in the SUMAL and a unique number will be generated for each document.

From the beginning of the timber transportation "from the cut/storage/acquisition/custody/loading place, after the release of the customs free in case of import, the notice issuer has the obligation of loading in the application online or, accordingly, offline (...) of all the standard information so it could be communicated".

One of the remedies that this Government Decision is bringing consists in the regulation of accessibility to GSM. Thus, in case the aforementioned place is located in an area covered by GSM, the notice issuer has the obligation of communicating online in SUMAL the standard information and the registration in the waybill of the unique code as well as the precise date, hour, minute and second generated by SUMAL. In case the timber loading place is in a GSM free area, the issuer of the waybill should upload the standard information in the application installed on the device that mandatory accompanies the transportation truck. The application generates an offline code that will be written on the waybill. In this latter case, when the transportation truck enters a GSM area, SUMAL generates the unique code, date, hour, minute and second that will be introduced in the waybill in maximum 12 hours from the generation of the offline code. ${ }^{16}$

Another positive aspect is the fact that the receiver of the timber has the obligation, before the reception of the timber, to enter the SUMAL system and check the authenticity of the unique code and date, hour, minute and second of the unique code generation.

The SUMAL system includes 3 elements ${ }^{17}$ :

a) client applications used by the professionals for:

1)registering or issuing the acts of valorization, the lots' exploitation authorizations, the minutes of force majeure, reports at the expiry of exploitation deadlines, documents of reengaging the lots and minutes of confiscations, all these being applications grouped in the SUMAL Forestry software ${ }^{18}$.

2)operating the timber waybills, the final deposit receptions and the mandatory management situations, all these being applications grouped in the SUMAL Agent software;

b) applications to track and control in real time the provenience and the way to ensure the traceability of timber;

c) the central unit - hardware and software -to centralize, process and analyze the information and control. The central unit is in the custody of the Special Telecommunication Service, called SUMAL Central.

The methodology concerning the organization and the functionality of SUMAL, the obligations of the SUMAL users as the structure and the means of transmitting the standard information were approved through the Order no.837/2014 ${ }^{19}$.

Besides the prohibition to introduce on the market illegally cut timber and products derived from it, another essential obligation mentioned just for the agents introducing timber and timber derived products on the market consists in the implementation and the application

\footnotetext{
${ }^{16}$ According to art. 3 from the Government Decision no.470/2014.

${ }^{17}$ According to art. 4 from the Methodology approved by Order No. 837/2014.

18 The SUMAL Forestry application is distributed to the forest districts and the software of tracking and realtime control of origin and means to ensure traceability of timber via the applications -Wood tracking Agent movable type (WT) -destined to state and private forest districts, and economic agents exploiting, transporting and marketing timber, and Inspector type mobile / desktop I wood tracking ( IWT ) -destined to inspection authorities or those who have legal powers to control the movement of the wood. In this respect see the provisions of Order No. 837/2014 approving the Methodology regarding the organization and operation of SUMAL, the obligations of SUMAL users, as well as the structure and the way to provide standardized information and the Order no. 596/2014regarding the approval of the Methodology for Testing the implementation of the Integrated information system for tracking timber.

${ }^{19}$... for the approval of the Methodology regarding the organization and functioning of SUMAL, the obligations of SUMAL users, as well as the structure and the means to provide standardized information, as amended and supplemented.
} 
of a "due diligence" system ${ }^{20}$. The essential elements ${ }^{21}$ that the "due diligence" system presumes in order to reduce to a minimum the risk of introducing on the EU market of timber or products derived from it, issued from illegally cut timber are:

a) The access of the agent to information describing the timber and the products derived from it, country of origin, quantity, furnisher data as well as other information regarding the observance of national legislation;

b) The evaluation of the risk of introducing on the market of illegally cut timber or products derived from it;

c) Reducing of the risks according to their amplitude when the evaluation indicates the existence of such a risk in the supply chain.

As an exception, the agents that do not operate the first introduction on the market but only forest exploitation through forest benefits, are not obliged to use a "due diligence" system [art. 4 paragraph (3)]. Also, the "due diligence" system does not apply to ornamental trees and shrubs, Christmas trees, osier and seedlings [art.5 paragraph (1)].

Regarding the legality of timber origin, the dispositions ofart.6 paragraph (1) from the Government Decision no. 470/2014 establish the conditions that should be met in order for the timber to be considered legal. These conditions are:

a) the existence of the valorization document approved according to the competences, of the exploitation authorization registered in SUMAL, and of the lot rendition notice;

b) the dispatch, possession, shipping, reception, storage, processing or trading of timber should be done with waybills having correctly marked the unique code generated by SUMAL and the date, hour, minute and second when it was generated.

Regarding these conditions, we notify that the legal dispositions require a cumulative completion of the conditions, meaning that in the situation when one of these conditions is not met, the timber does not have a legal provenance. In this latter case the premises for liability of the guilty parts are created.

Furthermore, we bring into notice another inconvenience, namely: according to art.2 paragraph (8) from the Government Decision no.470/2014 the forest districts and all the agents and traders that harvest, store, trade or perform timber import-export are bound to send monthly reports with the SUMAL data of the past month until the $15^{\text {th }}$ of the current month the latest. According to art. 6 paragraph (6) the timber for which the monthly report was not sent in SUMAL by the aforementioned professionals until the deadline mentioned in art.2 paragraph (8) is considered as not having a legal provenience. Thus, in the situation in which an agent providing the timber does not respect the reporting obligation, the provenience of the received timber becomes illegal. Consequently, a clarification is needed regarding the term "legal provenience", since the provisions from art. 7 paragraph (7) show that, in case of the presence of timber without documents clearly proving its legal provenience, the sanction of a fine and the confiscation of the timber is applied, according to art. 72 from the Forestry Code.

For the imported timber with import customs declaration or, if the case requires it, the FLEGT license ${ }^{22}$ as provenience documents, the legality of provenience is established if, from the moment of the customs release it is accompanied by waybills in which, besides the ordinary data, are correctly written the unique code generated by SUMAL, the date, hour, minute and second of its generation [art. 6 paragraph $(1 \wedge 1)]$.

\footnotetext{
${ }^{20}$ As provided in Art. 6 of Regulation no. $995 / 2010$ for the categories code - 4401, 4403, 4406 and 4407. According to the Annex to the mentioned Regulation, these categories refer to fire wood, raw wood, wood sleepers for railway or similar and timber longitudinally sawn or split with a thickness of over $6 \mathrm{~cm}$.

${ }^{21}$ In accordance with the provisions of the art. 6 of Regulation no. $995 / 2010$.

${ }^{22}$ See Regulation (EC) no.2173 / 2005 of December $20^{\text {th }} 2005$ on the establishment of a FLEGT licensing scheme for imports of timber into the European Community (FLEGT = Forest Law Enforcement, Governance and Trade in forestry)
} 
The lawfulness of cutting timber originating from the EU member states is certified through documents released according to the law applicable on their territory, in accordance with the provisions of the Regulation, and the legality of the timber harvest - legal provenience - is attested by FLEGT licenses and CITES certificates ${ }^{23}$, as provided in article 3 of the Regulation, and documents issued by exporting countries in accordance with the applicable legislation their territory[art.6 paragraph(2)-(3)].

The Government Decision no. 470/2014 is sanctioning with a fee not only the lack, but also the misuse of a "due diligence" system. Starting with January $1^{\text {st }} 2015$ it is forbidden to exploit standing timber by traders not using a "due diligence" system. Also, the Government Decision mentions sanctions regarding the lack of use or misuse of the SUMAL system.

We also mention the fact that recently was adopted the Government Decision no. $845 / 2015$ regarding the setting of certain obligations and sanctions incumbent on the agents who introduce for the first time timber products on the market, according to the Regulation (UE) no. 995/2010 of the European Parliament and Council from October $20^{\text {th }} 2010$ establishing the obligations incumbent on the agents who introduce on the market timber and timber products ${ }^{24}$,through which the obligations and regulations incumbent on the agents who introduce for the first time on the market timber and timber products are tightened, establishing the sanctioning regime for the agents not respecting the obligations mentioned in art.6 from the EUTR Regulations.

In conclusion, in the context of the increasing crime phenomenon of illegally cutting timber, the creation of an integrated information system was really necessary, in order to provide information related to the whole tracking and identifying timber, from the moment of harvesting it in the woods, exploitation and marketing, until its final processing or export.

The EUTR Regulation is instituting an essential obligation for the agent, namely to ensure he is not introducing on the market illegal timber, putting into practice a "due diligence" system. Thus, the SUMAL system represents a necessary and efficient mean of controlling the introduction on the market of illegal origin timber and constitutes the basis of the "due diligence" system intended by the (UE) Regulation no. 995/2010.

\section{BIBLIOGRAPHY:}

I. Treaties, courses

- Mircea Duţu, "Dreptul internaţional al mediului" (International Environmental Legislation), EdituraEconomică, Bucureşti, 2004;

-Daniela Marinescu, Maria-Cristina Petre, "Tratat de dreptul mediului" (Treaty of Environmental Legislation), ediţia a V-a, revised and amended, Editura Universitară, Bucureşti, 2014.

\section{Legislation}

-Law no.46/2008of the Forestry Code, republished, (the Official Gazette no.611 of August $\left.12^{\text {th }} 2015\right)$;

-Government Decision no.470/2014for approving the Norms on the origin, movement and marketing of timber, the regime of timber storage facilities and installations of processing round wood as well as measures for implementing the Regulation (EU) 995/2010 of the European Parliament and Council of October $20^{\text {th }} 2010$ establishing the obligations of

\footnotetext{
${ }^{23}$ In accordance with paragraph 10 and article 3 of EUTR Regulation, the CITES permits for export shall be granted only if a CITES-listed species has been harvested, inter alia, in accordance with the national law of the exporting country. In this sense the timber of species listed in Annexes A, B or C to Regulation (EC) no. 338/97 of December $9^{\text {th }} 1996$ on the protection of species of wild fauna and flora by regulating trade therein should be considered legally harvested provided it complies with that Regulation and any implementing provisions thereof.

${ }^{24}$ Published in the Official Gazette no. 771 ofOctober $15^{\text {th }} 2015$.
} 
operators who introduce timber and timber products on the market, with subsequent modifications and amendments,(the Official Gazette no.426 from June $10^{\text {th }} 2014$ );

-Government Decision no.845/2015establishing certain obligations and sanctions incumbent on operators who introduce timber products on the market for the first time, in accordance with the Regulation (EU) 995/2010 of the European Parliament and of the Council of October $20^{\text {th }} 2010$ establishing the obligations of operators who introduce on the market wood and wood products, (the Official Gazette no.771 of October $15^{\text {th }} 2015$ );

-Order no.837/2014for the approval of the Methodology regarding the organization and functioning of SUMAL, the obligations of SUMAL users, the structure and the means to provide standardized information (the Official Gazette no.761 of October $21^{\text {st }} 2014$ );

-Order no.596/2014regarding the approval of the Methodology for testing the implementation of the Integrated Informational System of Tracking Timber (the Official Gazette no.491 of July $2^{\text {nd }} 2014$ ).

\section{European Legislation}

-Regulation (UE) no.995/2010 establishing the obligations of operators who introduce timber and timber products on the market;

-Regulation (CE) no.2173/2005establishing a FLEGT licensing scheme for imports of timber into the European Community;

-Regulation (UE) no.363/2012 on procedural rules for proper recognition and withdrawal of monitoring organizations, stipulated in the Regulation (EU) no. 995/2010 of the European Parliament and of the Council establishing the obligations of operators who introduce timber and timber products on the market;

-The European Parliament Resolution of April $28^{\text {th }} 2015$ regarding “A new EU strategy for forests and forestry sector"/P8_TA(2015)0109;

-The Commission Communication of September 20 2013 named “A new EU strategy for forests and forestry sector"/COM(2013)659 final;

-The Commission Communication of June $15^{\text {th }} 2006$ concerning a European Union action plan for forests/COM(2006) 302 final.

IV. Other sources

http://www.europarl.europa.eu

http://eur-lex.europa.eu

http://legislatie.just.ro 